\title{
Opiates and the adrenal: the tip of the iceberg?
}

Ashley Grossman

Centre for Endocrinology, Barts and the London School of Medicine, London, UK
Correspondence

should be addressed

to A Grossman

Email

ashley.grossman@ocdem.

ox.ac.uk

Morphine-like compounds based on opium and derived from the opium poppy, Papaver somniferum, have been known for millennia, and their use recurs throughout the ages in personal reports and in world literature. For many decades their use was, if not fully condoned by society, tolerated as an effective means of ameliorating pain and indeed for 'recreational' purposes. The Opium Wars in the nineteenth century pitched the enthusiastic British traders in China against the local authorities who wished to control their use, with the eventual triumph of commercial capitalism and British firepower. In late nineteenth century London such opium dens were an accepted part of the Limehouse landscape, at least according to Charles Dickens, and frequented by wellconnected gentlemen; indeed Coleridge's epic poem Kubla Khan was said to be written under the influence of opium, while Thomas de Quncey immortalised the habit in his Confessions of an English Opium-Eater.

However, over time and especially in the twentieth century, such opium-like compounds, the opiates, increasingly became drugs of abuse in addition to their profound analgesic effects, with heroin in particular becoming a global scourge. In addition, various analogues of the opiates were synthesised, with varying potencies, hoping to emphasise the analgesic efficacy while limiting their addictive potential. Unfortunately, it has been difficult to separate these two factors, and with the active encouragement of pharmaceutical companies, drugs such as oxycodone have become a major source of addiction and distress. Thus, in addition to their widespread use as highly effective analgesic agents in medicine, opiates have moved from an illegal phenomenon as part of the global drug trade to a phenomenal prescription-agent problem in many parts of the developed world. It has been estimated that since 1999, 200000 Americans have died

https://eje.bioscientifica.com https://doi.org/10.1530/EJE-18-0820 (c) 2019 European Society of Endocrinology Printed in Great Britain from oxycodone and allied prescription opiates, while in recent years US clinicians have issued a quarter of a billion opiate prescriptions annually (1). The pharmacology of opiates has become literally of deadly interest. Thus, their pharmacology, and especially their effects on neuroendocrine axes, is of very considerable interest.

In 1973 Hughes and Kosterlitz described the endogenous opiate-like compound, met-enkephalin, as the first opioid (2). Subsequently, other opioids were described, the endorphins and dynorphins, and in due course their specific receptors were identified, principally $\delta, \mu$ and $\mathrm{K}$ (and possibly $\sigma$ ), with putative ligands of enkephalin, endorphin and dynorphin for the first three respectively. Animal studies revealed the presence of each of these opioid classes within the hypothalamo-pituitary axis, while experimental studies in humans demonstrated the effect of their exogenous administration. Many of these effects were similar to those seen after administration of opiates such as morphine. In terms of the neuroendocrine axes, in our studies as well as others, opioid analogues were able to potently suppress the release of the gonadotrophins FSH and LH (3) and of ACTH and cortisol (4); most studies suggested there were actions at the level of the hypothalamus, with suppression of gonadotrophinreleasing hormone and the ACTH secretagogue CRH-41 and probably vasopressin (5).

As the different types of opioid receptor was shown to have different sensitivities to antagonism with the opiate antagonist naloxone, varying doses of naloxone were administered to humans in different pathophysiological situations to reveal the nature and type of endogenous opioid 'tone'. Summarising very many of these studies, it was established that the hypothalamo-pituitary-adrenal (HPA) axis is subject to a continuous relatively invariant tone over $24 \mathrm{~h}$ requiring high doses of naloxone to reveal

Published by Bioscientifica Ltd. 
it $(6,7)$, while the gonadotrophins showed sensitivity to low doses of naloxone, with a tone which varied over the menstrual cycle (8), and which was dramatically increased in hyperprolactinaemia $(9,10)$. The amenorrhoea of hyperprolactinaemia may thus at least in part be opioid mediated. These potent effects of endogenous and exogenous opiates and opioids were not subsequently extended to any major extent, although it was realised that that there was profound suppression of the pituitarygonadal axis in those addicted to potent opiates such as methadone and heroin (11). Indeed, the effects of opium on sexual function had also been recorded down the ages, with a detailed description being given by the Persian physician Avicenna (Abu Ali al-Husayn ibn Sina), who was born near present-day Bukhara in Uzbekistan. However, when one turns to the pituitary and adrenal, rather surprisingly, effects on the HPA axis have been little studied, a serious omission in view of the considerable increase in prescription-opiate use and abuse, as noted above.

In the recent study by Lamprecht et al. (12), groups from Brisbane and Adelaide in Australia have attempted to explore whether and how relevant are the effects of opiates on hypothalamo-pituitary axes, particularly the HPA and gonadal axes. They recruited a group of 40 patients from a Chronic Pain Clinic and used a parallel control group of 25 subjects in order to assess the effects of opiate use on basal pituitary hormone status, as well as their responses to dynamic stimulation of the HPA axis. The patients were mainly on oxycodone, and they used a dose formula based on morphine equivalents whereby oxycodone is considered 1.5 times more potent than morphine. The two groups were then subject to baseline hormonal assessment as well as a short Synacthen test (ACTH(1-24) $250 \mu \mathrm{g})$ or a metyrapone test or both. The mean morphine equivalent dose in the patient group was $74 \mathrm{mg}$. The groups were then compared in terms of their basal and stimulated hormone levels, as well as their responses to a variety of questionnaires.

Assuming a basal cortisol of $<138 \mathrm{nmol} / \mathrm{L}$ was 'subnormal', they reported that $20 \%$ of their patients had subnormal levels compared to none of the controls. Overall, $22.5 \%$ of patients were considered to have failed the basal or simulated tests of cortisol reserve. This was rather higher than a previous uncontrolled study from Edinburgh (13). However, in the present study none failed if their morphine equivalent dose was $<60 \mathrm{mg}$ a day, while this was frequently seen in those on $100 \mathrm{mg}$ or greater. There was no significant of evidence of hypogonadism in either sex, any minor differences being probably accountable to changes in BMI, while the questionnaire analysis did not reveal any major unexpected findings.

One possible criticism of the study would be of the tests and criteria used to substantiate hypocortisolism. They used a serum cortisol of $250 \mathrm{nmol} / \mathrm{L}$ as their threshold for assuming a normal HPA axis, justified from several rather older studies, although others have suggested much higher values of the order of $350 \mathrm{nmol} / \mathrm{L}$ using most modern assays (14), and even higher with some assays. It is not often realised how assay dependent is the measurement of cortisol (15), so much care needs to be taken in extrapolating to other centres and laboratories without a clear description of the assay in use. Furthermore, most would use a significantly lower 30-min cut-off for a normal Synacthen test than the 60-min value they have used (15), although they reported normative results from their own centre. They are also one of the few centres utilising the metyrapone test as a measure of cortisol reserve. Nevertheless, taking the results as presented, there is little doubt that a substantial percentage of patients on opiates show a disturbed HPA axis, an important positive finding. But is this clinically significant, and if not, why not?

It is surprising that such studies have not been more in evidence in the endocrine literature, as quite clearly profound suppression of the HPA axis may have important clinical consequences. It would appear from this study that low doses of exogenous opiates are relatively sparing of the HPA and pituitary-gonadal axes and are thus unlikely to have any major sequelae. The lack of effect on the pituitary-gonadal axis, as reported here, is especially surprising and probably reassuring in terms of any requirement for endocrine replacement therapy. Previously, chronic opiate use has been strongly associated with gonadotrophin suppression (16), and indeed, many case reports such as our own have shown very profound inhibition of both pituitary-gonadal as well as pituitaryadrenal blockade after short-term use (17). It may be that these effects are highly dose and time dependent. However, the marked suppression of the HPA axis reported here, admittedly in a minority of patients and those on the highest doses, does raise significant questions as to the clinical significance of these findings. Most importantly, are these subnormal basal and particularly stimulated levels of cortisol associated with increased morbidity and possibly mortality? It is generally assumed that a subnormal response to ACTH(1-24) requires consideration of glucocorticoid replacement, at least during infective illness, trauma or surgery, but does this apply to this patient group? Are we unaware of significant morbidity in 
patients on high doses of opiates or is this a non-problem? For example, patients on potent opiates for pain relief, especially when prescribed for malignant conditions, may need to undergo surgery under general anaesthesia, but the impact of the assumed suppression of the HPA axis has not been determined. It is possible that there is another unknown mechanism that supports such patients and prevents catastrophic adrenal insufficiency and crisis, but this remains highly speculative. Likewise, does the use of potent opiate analgesic pre-medication compromise surgical survival? These are important questions which until now have been rarely considered and discussed, and the present publication is an important landmark study that such considerations are now being taken seriously into account. The authors do point out the difficulties in recruitment for this type of study, but clearly the topic is worthy of more extensive investigation. It would be of great interest to recruit a much larger cohort over time, and with a well-annotated cortisol assay it may not be necessary to run a parallel control group, while an ACTH stimulation test may be adequate without any further dynamic stimulation. We may have thought that we knew most of there was to know regarding the clinical assessment and treatment of changes in the HPA axis, but there still appears to be much to learn in the 'opiate story', suggesting we are just seeing the tip of the iceberg.

\section{Declaration of interest}

The author declares that there is no conflict of interest that could be perceived as prejudicing the impartiality of this commentary.

\section{Funding}

The research did not receive any specific grant from any funding agency in the public, commercial or not-for-profit sector.

\section{References}

1 Keefe PR. Empire of Pain. The New Yorker 2017, October 30th.

2 Hughes J, Smith TW, Kosterlitz HW, Fothergill LA, Morgan BA \& Morris HR. Identification of two related pentapeptides from the brain with potent opiate agonist activity. Nature 197518 577-580. (https:// doi.org/10.1038/258577a0)

3 Grossman A, Moult P, Gaillard RC, Delitala G, Toff WD, Rees LH \& Besser GM. The opioid control of LH and FSH release: effects of a metenkephalin analogue and naloxone. Clinical Endocrinolology 1981 14 41-47.

4 Gaillard RC, Grossman A, Smith R, Rees LH \& Besser GM. The effects of a met-enkephalin analogue on ACTH, $\beta$-LPH, $\beta$-endorphin and metenkephalin in patients with adrenocortical disease. Clinical Endocrinology 198114 471-478.

5 Tsagarakis S, Navara P, Rees LH, Besser GM \& Grossman A. Morphine directly modulates the release of corticotrophin releasing factor-41 from rat hypothalamus in vitro. Endocrinology 1989124 2330-2335 (https://doi.org/10.1210/endo-124-5-2330)

6 Grossman A, Gaillard RC, McCartney P, Rees LH \& Besser GM. Opiate modulation of the pituitaryadrenal axis: effects of stress and circadian rhythm. Clinical Endocrinology 198217 279-286.

7 Morley JE, Baranetsky NG, Wingert TD, Carlson HE, Hershman JM, Melmed S, Levin SR, Jamison KR, Weitzman R, Chang RJ, Varner AA. Endocrine effects of naloxone-induced opiate receptor blockade. Journal of Clinical Endocrinology and Metabolism 198050 251-257.

8 Moult PJ, Grossman A, Evans J, Rees LH \& Besser GM. The effect of naloxone on pulsatile gonadotrophin release in normal subjects. Clinical Endocrinology 198114 321-324. (https://doi. org/10.1111/j.1365-2265.1981.tb00202.x)

9 Grossman A, Moult PJA, McIntyre H, Evans J, Silverstone T, Rees LH \& Besser GM. Opiate mediation of amenorrhoea in hyperprolactinaemia and in weightloss related amenorrhoea. Clinical Endocrinology 198217 379-388.

10 Grossman A, Moult PJA, Cunnah D \& Besser GM. Different opioid mechanisms are involved in the modulation of gonadotrophin and ACTH release in man. Neuroendocrinology 198642 357-360. (https:// doi.org/10.1159/000124463)

11 Mendelson JH EJ, Judson B \& Goldstein A. Plasma testosterone and luteinizing hormone levels during levo-alpha-acetylmethadol maintenance and withdrawal. Clinical Pharmacology and Therapeutics 198435 545-547. (https://doi.org/10.1038/clpt.1984.75)

12 Lamprecht A, Sorbello J, Jang C, Torpy DJ \& Inder WJ. Secondary adrenal insufficiency and pituitary dysfunction in oral/transdermal opioid users with non-cancer pain. European Journal of Endocrinology. 2018178 353-362. (https://doi.org/10.1530/EJE-18-0530)

13 Gibb FW, Stewart A, Walker BR \& Strachan MW. Adrenal insufficiency in patients on long-term opioid analgesia. Clinical Endocrinology 201685 831-835. (https://doi.org/10.1111/cen.13125)

14 Sbardella E, Isidori AM, Woods C, Argese N, Tomlinson JW, Shine B, Jafar-Mohammadi B \& Grossman AB. Baseline morning cortisol level as a predictor of pituitary-adrenal reserve: a comparison across three assays. Clinical Endocrinology 201786 177-184. (https://doi. org/10.1111/cen.13232)

15 El-Farhan N, Pickett A, Ducroq D, Bailey C, Mitchem K, Morgan N, Armston A, Jones L, Evans C \& Rees DA. Method-specific serum cortisol responses to the adrenocorticotrophin test: comparison of gas chromatography-mass spectrometry and five automated immunoassays. Clinical Endocrinology 201378 673-680. (https://doi. org/10.1111/cen.12039)

16 Reddy RG, Aung T, Karavitaki N \& Wass JAH. Opioid induced hypogonadism. BMJ 2010341 c4462. (https://doi.org/10.1136/bmj. c4462)

17 Policola C, Stokes V, Karavitaki N \& Grossman AB. Adrenal insufficiency in acute oral opiate therapy. Endocrinology, Diabetes and Metabolism Case Reports 20142014130071. 